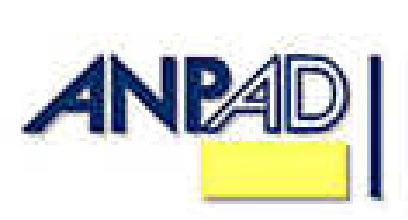

Available online at http://www.anpad.org.br/bar

BAR, Curitiba, v. 8, n. 2, art. 5, pp. 185-204, Apr./June 2011

\title{
Organizational Culture and Discourses: a Case of Change in a Brazilian Public Organization
}

Lindomar Pinto da Silva * Email address: lpsilva@sefaz.ba.gov.br Universidade Federal da Bahia - UFBA

Cidade Feira de Santana, BA, Brazil.

Élvia Fadul Email address:madm@unifacs.br Universidade Federal da Bahia and Universidade Salvador Cidade Feira de Santana, BA, Brazil.

* Corresponding author: Lindomar Pinto da Silva

Rua Adenil Falcão, 1823; Bairro Brasília, Cidade Feira de Santana, BA, 44088-744, Brazil.

Copyright (C) 2011 Brazilian Administration Review. All rights reserved, including rights for translation. Parts of this work may be quoted without prior knowledge on the condition that the source is identified. 


\begin{abstract}
This work analyses the use of the discourse as a strategy for the dissemination of new cultural values in a State Secretary beginning in 1995. For this purpose, discourse analysis was used according to the concept by Fiorin (1997) based on the concepts of figures, themes and ways to manipulate discourses. It is a descriptive and exploratory study. The theoretical discussion was based on the concept of organizational culture in the dimensions of artifacts and cultural values. The analysis was carried out from the documents of the organization, including the projects of modernization, plans of action, reports of strategic planning, laws and decrees. Furthermore, the official journal of the organization from 1998 to 2006 was analyzed. For the years 2007 and 2009 , the analysis was conducted based on the organization's website. The results show that there was deep concern with regard to the theme of organizational culture during the whole process of modernization. They also indicate that the organization used different discourse resources to guide the individual behavior of its members such as seduction, temptation, intimidation and provocation. They also show that the official discourses are not in harmony with the various discourses found in the organization due to the plurality of values that are shared by the organizational actors.
\end{abstract}

Key words: organizational culture; public organizations; cultural change; discourse analysis. 


\section{Introduction}

The emphasis placed on public sector organizations stems from the conviction that there are cultural distinctions in these organizations which distinguish them from private companies, and this would therefore lead to different directions and findings in studies of them. The cultural dimension stands out in the Master Plan of the reform of the state apparatus as a necessary element and as a central dimension to be transformed. Strongly based on bureaucratic values, this organizational culture would have to undergo changes capable of transforming it into a managerial culture (Plano Diretor da Reforma do Aparelho do Estado [PDRAE], 1995). Reform and change in the Brazilian public sector are not new phenomena. However, the state reform implemented in the 90s formalized through the Master Plan of the state apparatus reform PDRAE gained centrality in the political agenda and in academic discourse, not only due to its completeness or for being the most recent one, but above all, for bringing in its wake proposals for structural changes in the role played by the state in its relationship with society. The redefinition of spaces and roles by the state also brought about a change in the way public organizations should be run. The option of this study to set forth the process of reform that was initiated in 1995 is mainly due to the emphasis placed on the pursuit of transformation of the public sector culture and the emphasis placed on the civil servant as an essential element for the implementation of any process of organizational change in the public sector. From this scenario of changes in the public sector, the main goal of this work is to investigate how a public organization has absorbed managerial discourse and sought a cultural transformation.

The article investigates how new artifacts were included in the organization with the intention of developing new cultural values. For this reason, the study begins with this introduction and then discusses the main concepts of organizational culture and its elements. The following section presents a contextualization of the state reform processes and the methodological aspects. The next section discusses the main changes among the transformations of the organizational culture. It then presents the final conclusions.

\section{Organizational culture and its elements}

The different concepts of culture include elements such as: ideologies, groups of coherent beliefs, basic assumptions, groups of shared values, important comprehensions, collective wishes, collective programming of the mind (Sackmann, 1992), symbols, rituals, practices (Hofstede, 2003) values, visible artifacts (Schein, 2004), practices, meanings of practices and contexts (Dupuis, 1996) and other elements that enrich the discussion concerning organizational culture (Alvesson \& Berg, 1992), Aktouf (1994) values the mental representations in culture, the most important elements being symbols and myths. For him, "the organizational culture is supported and maintained by indispensable constitutive elements in particular by the myth" (Aktouf, 1994, p. 52). Of the elements of organizational culture outlined above, some will be briefly dealt with because they are used more in detail in this work: visible artifacts (written norms, structures, rituals) and organizational values.

Visible artifacts are the result of the social interactions of individuals. They result from a collective social construction that material objects, the artifacts, would represent, the perception of what is important for individuals within the organization. Another way to perceive the artifacts is to understand them as a sign of what these values represent for the organization and which it believes are necessary for organizational success. In this case, the analysis of the visible artifacts must figure out what symbolic representations they have for both for individuals and the organization. Schein (2004) considers these elements to be of easy visualization, but of difficult interpretation. Sackmann (1992) considers that the meanings of the artifacts are located in deeper levels of cultural comprehension; hence, it is difficult to understand and grasp their meanings. However, Sackmann (1992) argues that the artifacts are important because they actually express meanings attributed by members of the organization. However, the difficulty lies in other reasons, in the fact that the same events and artifacts can bear different meanings to members of the same organization, not to mention the fact that some artifacts can only exist as an "old-fashioned routine that belongs to a bygone era whose meanings are 
no longer relevant to the dominant group of organizational actors" (Sackmann, 1992, p. 142). Therefore, the comprehension of the cultural meanings of artifacts requires adequate attention by the researcher if he wishes to understand the shared meanings of the organizational artifacts in their entirety.

Deal and Kennedy (2000), referring to one of the components of the artifacts, the rituals and the ceremonies, understand them to be important not only for the identification of a strong culture, but also for the preservation of this same culture. For these authors, "without meaningful events, any culture dies. In the absence of ceremonies or rituals, important values have no impact at all" (Deal \& Kennedy, 2000, p. 63).

In this sense, rituals and ceremonies, as well as the other elements that compose artifacts, have the function of preserving the values necessary for the maintenance of the organization. In the cases mentioned, Schein and Deal and Kennedy, a functionalist view of culture can be perceived. For the authors, the artifacts have a specific function that is the creation or maintenance of values that are necessary for organizational life. However, as for the interpretative view of culture (Geertz, 1989), cultural artifacts are symbolic representations of what the members of the organization share about their culture. And this aspect is not necessarily related to the instrumental relation of cultural artifacts with organizational performance (Alvesson \& Berger, 1992), since artifacts are not only the production of the mind of managers, but social constructions of the individuals themselves that are represented through these artifacts (Gagliardi, 2001, p. 132).

For this reason, there is a need to pay attention to the underlying interpretation of each element of organizational culture. Moreover, Gagliardi (2001, p. 132) characterizes well the importance of the artifacts for cultural understanding. According to him:

the need to study the artifacts is particularly significant for those who embark on the exploration of organizational cultures, i.e., as systems of symbolic meaning, for at least two reasons. First, it seems reasonable to guess that the artifacts are not secondary and superficial manifestations of a deeper cultural phenomenon, but are a primary cultural phenomenon that influences corporate life based on two distinct points of view: (a) artifacts make it practically possible to favor, hinder or even prescribe organizational action (b) in a more general way, artifacts influence our perception of reality up to a point of shaping, in a subtle way, beliefs, norms and cultural values. Furthermore, if someone is concerned about the organizational symbolism, they should not forget that symbols are embodiments of the senses and things that form their most common and natural environment (Gagliardi, 2001, p. 132).

This shows the importance of the comprehension of the meanings impregnated in the cultural artifacts since they can function as clues to ways of seeing and feeling of the social actors. This is because, unlike rationally planned answers even in direct interviews, the artifacts are always present, permitting a more realistic measurement of the meanings of material symbols.

Organizational values and beliefs are less clear and more difficult to even observe. Consequently, their interpretation and their role in organizations are more difficult. However, they are a fundamental element in the analysis of the cultural organization. Schein (2004) believes the values to be the only proper way to behave. Values are the guides of individuals' behavior within organizations. Deal and Kennedy (2000, p. 21) define values as a "background of any corporate culture. Like the essence of the company philosophy to achieve success, values serve as a sense of common direction for all the employees and a guide of behavior for their everyday life.

Organizational success depends on a clear comprehension of values and of their internalization and practice by all employees. Schwartz (1994) considers these values to be the true guides of human behavior and thus he considers them as: 
(a) beliefs related to emotion (b) values representing a motivational construct being related to desirable goals which people seek to achieve (c) values transcending specific situations and actions characterized by abstract goals, (d) values guiding the selection and assessment of actions, people and events that can be considered standards or criteria (e) values ordered by relative importance compared to others, forming an 'orderly' system for each human being (Schwartz, 1994, p. 20).

What depends on these concepts is that the values serve to motivate human behaviors and should certainly be part of individual and collective values. In this regard, Hofstede (2003, p. 23) considers values "as a tendency to prefer a certain state of things compared to others". Machado-daSilva and Nogueira (2000, p. 11) agree up to a certain extent with Hofstede when they see values as "standards of judgment whose shared meanings indicate what is preferred or wished and can express the idea of how reality, idealization or ideal is or should be". Within organizations, values are normally part of their declaration of values. This is based on the idea advocated by Schein (2004) and Kotter and Heskett (1992) that when defining and claiming values and making them public as proposed by Pettigrew (1996), practice will favor the internalization of these values.

Whereas values represent the senses that guide behavior, the artifacts are the visible parts of the values such as plans, structures, projects and behavior. As a consequence, when understanding the behavior of an individual, you would understand the values that cause him to behave in such a manner, and organizations like the one under study here, use this concept of values in an attempt to modify their organizational culture.

\section{Brazilian public administration: organizational environment and management models}

Brazilian public administration has historically been built and reinforced over several decades in a trajectory marked by reformist movements that

are located in some episodic moments of political and institutional crises in which the country was involved, as well as in periods in which the Brazilian State itself underwent moments of crises that required a restructuring and revision of its development policies and strategies (Fadul \& Souza, 2005, p. 1).

A quick and brief historical overview of the formation of the institutional context in which Brazilian public institutions are inserted and act on suggests significant features that the reforms which occurred in Brazilian Public Administration have left an imprint on the management models and consequently on the organizational culture of the public sector itself that will be outlined below.

The reformist movement that took place in the 1930s with the creation of the DASP includes in its basis the adoption of the management principles recognized scientifically as the prescriptive model of administrative theory at that time with emphasis on the areas of personnel administration with the definition of professional criteria for entry into civil service, career development and the establishment of promotion rules based on merit (Marini, 1996, p. 17). Creating legal rules, ways of access to public office and rules of conduct for civil servants that would be out of the area of influence of politicians, considered those interested in taking advantage of the civil services. The reform of the 1930s built and consolidated the Brazilian bureaucratic model, seeking a division between politics and administration, trying to break with a heritage culture, which is understood as the private use of what is public, i.e. the appropriation of res publica of the state apparatus and the state itself by special interest groups granting the concession of governmental benefits to a specific client or political group in exchange for favors, which was the system in force at that time, inherited from the Portuguese colonization.

On the other hand, decree-law number 200/67, besides initiatives of administrative restructuring in different sectors of the federal administration, brought about an important innovation. This was the introduction of managerial values into public administration, and it developed in a wide variety of 
organizations of indirect administration, a managerial culture similar to the model stemming from the economy of the private sector.

In turn, the political institutional decentralization brought by the constitution of 1988 revisited the debate concerning the historically authoritarian relationship between the state and society, opening channels of dialogue and participation in the process of formulating public policies with greater transparency in management, with impacts on the culture of public organizations.

At last, the historical landmark that motivated the writing of this article, the reform that has been implemented since 1995 through the PDRAE, also known as managerial reform, was intended to overcome the weaknesses of bureaucratic public administration. It sought to introduce into the Brazilian public administration a model of management focusing on efficiency in the pursuit of results and quality in services rendered to citizens (Bresser-Pereira, 1998).

An analysis of the Master Plan of reform of the Brazilian state apparatus reveals the importance given to what was designated as managerial culture. The state should make the necessary efforts to create and maintain a managerial culture able to endure the changes that were implemented. Therefore, the Master Plan emphasizes that the "introduction of the new managerial culture, centered on results in administrative competition and based on performance assessment, would allow more structural changes in the planned direction" (PDRAE, 1995, p. 57). The organizational culture is thereafter treated as the major trigger of management change.

Despite the association of these management models - patrimonial, bureaucratic and managerial - with the reform processes of the Brazilian public administration that occurred in the country, this does not mean that these models succeeded in history, with one being abandoned or overcome while another was installed. It is possible to perceive in Brazilian public organizations, even the most recent and innovative ones, such as the regulation agencies, patrimonial, bureaucratic and managerial features present in its management models.

The management models here presented mean each one at its time as a set of political practices and organizational cultures that prevailed at a specific historical time in Brazilian public administration, and its evidence can be analyzed under the light of administrative practices through which public business are being held. This association was made by using historical periods for the specific purpose of contextualizing and highlighting the elements of the organizational culture that shaped Brazilian public administration during its history.

\section{Methodology}

The research is of a descriptive-exploratory nature that seeks to investigate, describe and explain the phenomenon that was analyzed. It uses discourse analysis as a tool for analyzing the data. Understanding that culture is a social construction consisting of a network of meanings and that discourse also represents a social construction which expresses the meanings shared by individuals, discourse analysis is adequate to carry out this stage of the research. It is here considered that the use of organizational discourse analysis is an essential method because the discourse reveals the main characteristics of the organization (Marshak, 1998), is interwoven with actions (Woodilla, 1998), contributes to the construction of meanings (Sillince, 2007) and also builds identities, abilities and emotions (Hardy, Laurence, \& Phillips, 1998). The discourses carry within themselves the meanings that are important and essential elements of organizational life.

Alvesson (2004, p. 331) states that "the discourses are arranged and integrated by cultures, but also represent (perhaps most importantly) the environment in which the cultures are built, reproduced, refuted and modified". Then the organizational discourse is conceived as "a collection of texts incorporated into practices of speech and texts (as well as in a vast variety of visual representations and cultural artifacts) that are related to objects in the way that these are produced, spread and 
consumed" (Grant, Hardy, Oswick, \& Putnam, 2004, p. 3). For this reason, discourse analysis holds an adequate methodology for the understanding of cultures.

The data analysis was carried out based on the concept of discourse by Fiorin (2007, p. 17). For this author the discourses

are combinations of linguistic elements - sentences or sets made up by many sentences - used by the speakers with the intent to express their thoughts, to talk to the outside world or to their inner world, to act upon the world.

And the dimensions of the analysis of the discourses were figures and themes. The figure represents a word that refers to an object of the real world such as a tree, the sun, a meeting, career plans and awards, while the theme has a semantic investment of a conceptual nature that does not refer to the natural world such as pride, meanings, values and senses. The themes represent arranged categories that permit the association of previously determined figures and themes. Hence, to identify these figures (concrete elements introduced in the organization) and the themes (values, meanings and senses) that are associated with those figures is the objective of this work.

Another analysis conducted in this work refers to the identification of the ways that the upper management used the discourse resources, mainly manipulation, to convince individuals of the necessity to adhere to the new values it spread. The ways of manipulating are temptation, seduction, intimidation and provocation. Temptation consists of proposing to the individual a reward in exchange for doing something. Seduction happens when the manipulation gets the individual do something that is wanted, expressing the abilities of the person that is being manipulated. Intimidation happens when the individual is threatened to make him do something, while provocation occurs when the manipulator expresses negative judgments about the ability of the manipulated person (Fiorin, 1997, p. 30). Finally, the last instrument of analysis refers to the lexical choice that describes the favorite expressions used by the producer of the discourse in order to contribute to the process of convincing the other person (M. M. P. Souza, Carrieri, \& Faria, 2009).

In these ways, the discourse of upper management is used as a vehicle for the transmission of cultural values and meanings. It uses the different forms of manipulation to convince the members of the organization as to how to guide their behavior based on these new values and meanings. Therefore, the figures represent the actions, artifacts and the other material instruments of the real world used to reflect the themes (values, and meanings) that the upper management wishes to see introduced into the collective imagination of its employees.

This work is also characterized by the longitudinal cut since the investigation covers a historical evolution of the period 1995 to 2009 . The documents of the modernization projects were analyzed as well as the project of strategic planning and the reports of the results that were obtained, in addition to the news divulged in the official journal of the organization: SEFAZ NEWS, which was used from 1998 to 2006 and ceased production in early 2007. Thereafter, the news of the organization has been analyzed since 2007 on the organization's intranet site.

Other sources of information were the Union of the Tax Civil Servants of the State of Bahia (Sindsefaz), the Institute of Fiscal Audits (IAF) on their Internet sites as well as field notes taken by researchers that were in the organization to obtain data during the period between January and December of 2009.

\section{The change and insertion of new organizational values: data analysis}

The Finance Department of Bahia (SEFAZ-BA) is an agency of the state government's direct administration, founded on August 16, 1895, and its current mission is to provide and administer financial resources in order to make viable the public policies of the state and explain to citizens why it is important to pay taxes. The SEFAZ-BA began its modernization process more systematically in 1995 , and the organizational culture has been analyzed and proposals for change have been made since 
the process began. It is interesting to point out that this is not a specific discourse by the SEFAZ-BA. On the contrary, it is a discourse of a much larger field present in the scope of managerial reform as foreseen in the PDRAE (1995). The idea of the necessity to transform the culture of the public organization stems from the PDRAE: "the obstacles to an efficient public administration can only be overcome when, together with an institutional-legal change, a cultural change occurs, leading it towards managerial public administration" (PDRAE, 1995, p. 38).

This discourse about cultural change also permeates the policies of the proposals by the InterAmerican Development Bank (BID - Banco Americano de Desenvolvimento) which backs up the National Program of Support to the Fiscal Administration for the Brazilian States (PNAFE), run by the Ministry of Finances of Brazil, which operationalized the whole project with the Caixa Econômica Federal. According to the Pnafe (Programa Nacional de Apoio à Administração Fiscal para os Estados Brasileiros [PNAFE], 1996) project, there was a need to invest in projects that could make cultural change in the public sector viable. Among the policies of the projects it is stated that: "institutional strengthening includes the definition of actions that represent a strong investment in the development of human resources in order to make viable the cultural change required by the modernization processes" (PNAFE, 1996, p. 17).

Similarly, in the SEFAZ-BA organization the discourse about cultural transformation is also present and has become a constant quest by the administrators as a way to make viable the process of modernization. Explicitly, the organization at the beginning of the process, not only emphasizes the importance of the cultural change, but also mentions cultural elements such as beliefs and values. Moreover, throughout the process it can be noted that cultural change was a clear goal to be achieved as mentioned below: "the premises of the administrative reform of the state were fulfilled in their totality by the model set, as well as the relative aspects beliefs and values of the organization" (Secretaria da Fazenda [Sefaz], 1998, p. 2).

An initial analysis describes the alignment of the discourse of the modernization project at SEFAZ-BA with other discourses that are external to it. There is in this case a full connection between the discourse of the state managerial reform, the BID and that of the organization. This relation refers to the concept of dialogism by Bakhtin (1993), meaning the recurrence that a discourse causes upon other existing discourses to strengthen or refute them, as well as what Sillince (2007) warns of the influence of external discourses on the discourses of organizations. Furthermore, in this case it is important to note that since the PNAFE consisted of a funding program for modernization projects, it was necessary for the states to submit themselves to certain pre-requirements in order to be eligible for the resources provided by the program.

Another important aspect in the analysis of the initial process of change is the view of the existence of a link between organizational success and organizational culture. Throughout the change processes, it was possible to see that signs were given that the cultural change was not only important, but also necessary for the success of the enterprise. This vision refers to every functionalist discussion of organizational culture, in addition to what Alvesson and Berg (1992) and Alvesson (2007) say about the causes of growing interest and popularity regarding organizational culture.

The same view that cultural intervention could create strong cultures that would help in the organizational mission (Deal \& Kennedy, 2000; Schein 2004; Ouchi, 1982) was imported from the outside world. From this perspective one can identify this discourse in the publications of the organization, among which the following statement stands out:

It was thus a profound cultural change, in which the bureaucratic administration was transformed into a managerial administration. Efficiency and effectiveness became principles of the state's public administration. Therefore, in the present context, SEFAZ-BA is an organization that seeks results and competence and is concerned with the satisfaction of its clients and collaborators (Sefaz, 2003, p. 1). 
The first action that was implemented by the SEFAZ-BA was the Market Management Program (PGM). Defined as a tax collection control tool, its main goal is to provide managers with the opportunity to monitor the performance of tax collection in the unit under their responsibility. The PGM "consists of the segmentation of tax payers and the creation of specialized management departments by economic sector, introducing a new method based on an overall business view and a management model based on result and meritocracy" (C. R. S. Souza, 2002, p. 1). In this discourse, the figure of the PGM refers to important topics already mentioned in the managerial reform, i.e. focus on results and meritocracy (PDRAE, 1995). It is the first formal tool whose goal is to develop, mainly in the managers, management value by results. PGM paved the way for a new tradition, which also focuses on results. This came to be known as the Achievement of Goals Meeting. Beginning in 1995, this is a quarterly meeting at which the managers of each unit are called on by the finance secretary to report on the performance of their unit. The official journal of the organization, the SEFAZ NEWS, from 1995 to 2006, always reported these meetings, the following statements being points in question: "the XXVII Achievement of Goals Meeting evaluates the tax collection in the second semester. Managers of SEFAZ met on July 26, 2002 to evaluate the tax collection of the second quarter (SEFAZ NEWS, 2002a, p. 5). "During the XXXI Achievement of Goals Meeting, the SEFAZ leaders were presented with the result of the performance indicators set for all units of the secretariat in the first quarter of 2003" (SEFAZ NEWS, 2003a). It can be said, in accordance with Deal and Kennedy (2000), that this meeting served for senior administrators as a means of reinforcing values to be instilled especially in the managers when the PGM was created in 1995: focus on results.

The second major project to modernize the organization began in 1996, with the establishment of the Quality Program. Consisting of a set of measures to improve the organization, the Quality Program became increasingly important from 1997 onwards, due to the SEFAZ-BA's entrance into the PNAFE.

The Quality Program sought to "guarantee a uniform standard of services in all areas, its main goal being client satisfaction" (Secretaria da Administração, 2002, p. 220) and "used tools or systems recommended by Total Quality to stimulate the personal and professional growth of civil servants, the result being the improvement of the services rendered to the taxpayer/citizen who comes to the finance inspection offices and regional bureaus" (Secretaria da Administração, 2002, p. 127). To achieve these goals, the Quality Program is directed toward team development, implantation of the 5S method, routine management and development of behavioral actions.

Employees were mobilized and encouraged to provide more efficient client service. At these meetings, employees were also encouraged to make suggestion to help provide a view of a better management. Besides integrating the team, these events provide opportunities to promote major growth in the SEFAZ employees 'professional and personal life (SEFAZ NEWS, 2000a, p. 3).

SEFAZ continues its drive for quality, and by the end of the year will have implemented the stages of the program in all the bureaus of the north and south offices. The idea is to standardize service and work routines in all its units so as to provide both the civil servant and the taxpayer who comes to the bureau with greater comfort and efficiency (SEFAZ NEWS, 2001a, p. 5).

From the various actions undertaken by the Quality Program, besides lectures and seminars, the so-called D-Day stands out. This was a day set aside to present to the outside public the results of the training program and the development of the philosophy of the Quality Program. This occurred after an effort of the whole team of the unit whose goal was to arrange the work environment adequately. However, it has to be recorded that throughout the Quality Program, some employees preferred to distance themselves from its activities because they believed that they were an instrument of alienation that was being used to minimize resistance to the organization and unresolved claims on the part of the organization. From the analysis of the activities of the Quality Program, it is possible to see that it is linked to several issues that are considered part of the SEFAZ-BA's organizational culture, issues such as: efficiency, teamwork, importance of the external client, standardization of activities and 
employee valuation. These are recurring themes in conversations with those responsible for the actions carried out based on the Quality Program. The Quality Program provides an understanding of how the organization created and systematized a set of rituals that sought to develop the values associated with the issues mentioned above. Once more, it is in alignment with the concept of Deal and Kennedy (2000), Kotter and Heskett (1992) that the actions carried out by the organization could insert the culture of desired values into the level of invisible elements. This means that systematic rituals can create strong cultures.

As for the ways that the organization involved its employees, it is possible to identify find the manipulation strategies mentioned by Fiorin (1997), as well as those described by M. M. P. Souza, Carrieri and Faria (2009). The lexical choices show the way the civil servants were convinced of the importance of the change that was taking place. Terms such as client team and comfort are used by the board as ways of influencing individuals to adhere to the project that is being presented. Furthermore, according to Fiorin (1997), manipulation can be seen in the importance of these changes for the well-being of the employee himself.

The implemented change also affected the organizational structure, since it was considered inadequate for the challenges proposed by the public administration that was being introduced at that time, as can be seen in the following quotations:

The existing organizational structure is excessively bureaucratic, creating barriers to decision taking and difficulties in the flow of information among the managing offices and the operational base (Sefaz, 1997, p. 15).

For the actual modernization of the machinery of the treasury, making it a support tool for the creation of results with efficiency, the organizational restructuring of the SEFAZ organs directly or indirectly involved in the activities of tax collection and control is necessary (Sefaz, 1997, p. 8).

Consequently, the organizational structure of the SEFAZ-BA was associated with issues of bureaucratic processes that were slow, inefficient, disintegrated and did not allow the organization to focus on results. The organizational restructuring took place in 1999. Among the desired objectives was a drive for flexibility, efficiency, agility in client service and satisfaction as well as improvement in working conditions. A more visible decrease in hierarchical levels of the organization resulted from this process of structural modification "the organizational structure was reformulated, reducing the number of hierarchical levels from six to three. This enabled greater operational agility" (Secretaria da Administração, 2002, p. 223).

In the organizational structure, important issues for organizational life were focused on. The top management saw it as bureaucratic, slow and rigid, and the modification process sought to make it agile, flexible and efficient. As the modification of the organizational structure occurred in January of 1999, there was no news on this event published in the issues from 2000 to 2006. This new organizational model, proposed in 1998, in effect from 1999, had already been idealized as early as 1997, when the first steps of the PNAFE were taken. According to the project of structural modification it was necessary "to give the SEFAZ an agile and flexible organizational structure with fewer hierarchical levels, making it easier to communicate and take decisions" (Sefaz, 1997, p. 20). It is important to examine how these measures are associated with the view of managerial culture (Pettigrew, 1996) and with the Schein (2004) division in the level of organizational culture.

Meritocracy began to appear more consistently in the organizational discourse in 2001, with the implementation of the Award for Tributary Performance (PDF) and early 2002 with the implementation of the System of Performance Assessment of the FISCO Group - GDFISCO. It can be observed however, that the GDFISCO was only introduced in January 2003, but in late 2002, the publications of the SEFAZ NEWS had already mentioned the topic. The PDF is an award established in 2001 whose goal is to encourage employees for super action in tax collection goals. Once the goals of tax collection during strategic planning have been defined, it involves the managers and their teams 
developing local projects that enable them to achieve these goals. The goals are distributed by regional boards and subdivided by the units, with the sum of results of the units corresponding to the result of the regional boards, which in theory involves all the units in the effort to achieve their goals to contribute to the overall goal of the board to which they belong. Moreover, the PDF is only distributed if the tax collection goals of the whole state have been achieved. This means that, to be awarded, it is not enough that one unit obtains the result. In this process, it is possible to see beyond the focus of the outcome (increased tax revenues) another perspective, which is the pursuit of commitment (teamwork) toward an overall result of both the Regional Board and the performance of the state itself.

There are fewer statements in the official publications concerning the PDF as a tool to encourage the super action of goals. As it is a consequence of tax collection that is accountable at the Achievement of Goals Meeting, the PDF has possibly been included in the context of goals and has lost its space in discussions, despite its significant value for being an important part in the rewarding of the SEFAZ-BA civil servants. However, what is clear from the absence is the possibility of this effect on the culture of this organization to a point of making it part of its cultural meaning, i.e. it is not a web of meanings built socially by individuals, so it does not represent the same meanings for all the individuals (Geertz, 1989). It is worth noting that:

Among the actions highlighted in 2001 is the award for Public Treasury Performance (PDF) introduced in February 2001 with the aim of rewarding the performance and joint effort put into the increase of state revenues. Based on seven policies, the PDF has become an important tool of valuation and incentive concerning fiscal work proven through the achievement of tax collection goals set for each semester (SEFAZ NEWS, 2001b, p. 3).

In the publications that were analyzed, as well as the information that is available on the Intranet of the organization, the PDF is only mentioned when some changes are made in its methods of assessment and investigation or when its payment to the civil servants is announced. This seems to indicate what has already been mentioned above; the inability of this tool to have become a symbol within the symbolic representations for the members of this organization. In this aspect, it is important to refer to the critique made by Aktouf (1994) concerning the inability of the organization's managers to create, modify or destroy elements of culture as if they were only one more variable within the organizational subsystems.

In the artifact of the PDF another form of manipulation used by senior management can be identified. When this tool was proposed, its purpose was to involve employees in the organizational results. For this, lexical choices are important. Thus, expressions such as results, meritocracy and rewarding are recurrent in the PDF creation process. Manipulation is also seen by the temptation to propose a reward for the action concerning the desire of senior management (Fiorin, 1997). Allurement can also be found in that the goals are always set with a discourse of the competence and ability of the group and that they are capable of achieving it. In this case there is greater emphasis on the positive values of the employees and which would help them achieve results.

At this point, it is necessary to make an important observation. While the upper management saw in this artifact the meaning of results, commitment and teamwork, part of the group of organizational actors saw it as a way of allurement, a detour from the focus on the struggles of the workers. The union had been striving for years to increase the wages of the members of the organization, in addition to making other claims that remained unanswered by the organization. Therefore, when the PDF was introduced, one of the first conclusions of the union was that the government wanted to bend the law and not give a wage increase to retirees, to mention just one interpretation. As the PDF is an award, the government considers that this payment is not part of the other benefits such as vacation, thirteenth salary and retirement plan. This discourse of the union continues until today and has become increasingly noticeable due to the recurring insistence for the inclusion of the PDF into the base wage. A more recent action about what took place is mentioned in the following extract: 
Sindsefaz, as petitioner and legitimate representative of all the civil servants of the Finance Secretariat of the State of Bahia has taken to court today, the 27 of January, the collective execution of the Security Order whose decision recognizes the right of the retired civil servants and the pensioners that belong to the FISCO Group to have included in their retirement incomes and pensions the Award for Public Treasury Performance (PDF) (Sindicato dos Servidores da Fazenda do Estado da Bahia [Sindsefaz], 2010).

This news item is demonstrative of the inability of the organization to develop and maintain the myth of the big family. This will be discussed later. The emphasis on petitioner and legitimate representative of all the civil servants is a reference to other discourses that permeate the organization, especially to the IAF that was established to represent part of the SEFAZ-BA civil servants. In the model of dialogism by Bakhtin (1993), the Sindsefaz discourse is based on the discourse produced by the Institute of Fiscal Audits of Bahia - IAF which considers itself the representative of the fiscal audits while Sindsefaz seeks to be the single representative of all the civil servants. IAF and Sindsefaz have waged a private war that divides the organization into two equal parts. Hence, the discourse of the big family that started as far back as 1996 with the quality program and was continued in 2001 mainly with SATISFAZ, has been unable to stand as a symbolic representation for the members of this organization, and yet the organization continues nowadays with other actions in an attempt to build this big family called Sefaz.

At this point, what is complex in the cultural interpretations can be pointed out. Each organizational group can interpret the initial assumption of the PDF. Whereas for the organization the figure of the PDF represented the theme of a quest for results and commitment, other groups saw in the same figure themes that were totally different concerning the intent to separate the active servants from the retired ones. Therefore, the cultural interpretations must be analyzed in the light of discussions by Meyerson and Martin (1987) that represent more adequately the differences of sharing cultural meanings in an organization.

The GDFISCO is an evaluation system of employee performance of the SEFAZ-BA fiscal group that is used every two years. Based on these evaluation processes the promotions of employees to higher levels with an increase in salary occur. The goal of the GDFISCO is to:

(a) contribute to the differentiation and recognition of individual performance (b) make the civil servant aware of the organizational goals and his/her role in achieving these goals (c) aid the civil servant's development (d) subsidize and promote the civil servant (e) provide exchange of perception between leaders and employees (f) stimulate the strengthening of teamwork ( $\mathrm{g}$ ) maximize the results for the organization (Sefaz, 2003, p. 9).

It is important to note that in the same line as the PDF, the GDFISCO is implemented with goals that are important regarding the SEFAZ-BA policy in the development of new cultural values within the organization. Moreover, as the system is to help in the process of systematic promotion, other criteria are used to this end: the academic education and the systematic participation in courses during the evaluation period.

In the GDFISCO, some topics are present for the organization. As mentioned in this work, the organization in its projects always emphasizes the importance of cultural change. With the GDFISCO it is no different. The following is mentioned: "It is a cultural change, a true breaking of paradigm, as it is a performance evaluation" (SEFAZ NEWS, 2002b, p. 5).

The first care we took when introducing the GDFISCO was to form culture and create the figure of the leader-educator. The gratifying thing is that the servants, in general, understood that this is a constructive process, and is thus well accepted. We see this year as an exceptional one, as a year of implantation, strengthening, adjusting, apprenticeship of the process and consolidation of culture (SEFAZ NEWS, 2003b, p. 4).

The GDFISCO and its main topics occupied the internal publications for a significant period of time. Among the topics that have been most addressed by the implementation of the GDFISCO are 
teamwork, meritocracy, self development and maximization of organizational results. Among the criteria of the evaluation of the system there is a need to assess the ability of the individuals while working in a team in favor of positive results for the organization. Moreover, several statements can be cited to reinforce this perception:

The goal of the DRH is that the use of the GDFISCO should contribute to the civil servant feeling recognized and being aware of his/her role in the group, thus enhancing teamwork and establishing a climate of major exchange of result maximization (SEFAZ NEWS, 2002b, p. 4).

At the SEFAZ, for example, the philosophy of meritocracy was used in the concept of GDFISCO that began to be implanted in the bureau in October of last year. So, given the specificity of the public service, the performance evaluation for merit becomes an instrument of crucial importance for professional development and an encouragement for self development (SEFAZ NEWS, 2003b, p. 2).

After the July 2003 issue, the GDFISCO practically disappeared from the news of the organization, at least in terms of publication in the SEFAZ NEWS. Implementation problems caused the process to slow down the implantation. The process was only restarted in July 2004, one year after the latest news. The interruption was due to the resistance by the employees that are said to have hampered, back in 2003, the conclusion of the other steps of the process. After this, the following steps were restarted and in July 2005 the first evaluation of performance in the organization was carried out. Once more it is worth observing the difficulty to insert into the minds of the individuals new culture values based on new artifacts.

The case of the GDFISCO as to the ways of manipulation comes up differently than the previous tools. There existed the strategy of temptation when joining the system of promotion; but on the other hand, intimidation stands out to the extent that the non fulfillment of activities would result in punishment for individuals (Fiorin, 1997). However, regarding the lexical choices, the manipulation strategy emphasizes the expression professional development. It points out the possibility for individuals to advance in their career if they adhere to the model that is proposed by the evaluation system (M. M. P. Souza et al., 2009).

As for professionalization and meritocracy, the upper management, the union and the IAF seem still not to have advanced to a point of transforming the discourse into practice because of their disagreement over understanding what professionalization would actually be. For the union it would mean solving the problems on their demand list, which includes the modification of the career of the tax collectors as well as the creation of a career plan for the administrative technicians mainly because, for the union, the work carried out by these servants bear formal and legal modifications in their functions.

For individuals, observations during the period of data collecting showed how this value still did not represent a reality in the organization. The years 2006 and 2007 are representative of manifestations by symbolic representations that are present in the imagination of the individuals with the change of government. On the one hand the behavior of the group of administrators who, aware that they would leave their office, attempted to approve projects of their interests and because of this, they formalized their resignations from their office. On the other hand there was the union that gave its opinion, even informally, that when the government is changing, the posts have to be modified as well.

Hence, professionalization has not yet become a symbol present in the life of the members of the organization. This topic comes to a close with a statement by a member of the organization: "it came as no surprise when we arrived at the meeting of planning and found there $50 \%$ of the administrators from the former government. I could not believe that these people were still there as managers" (discourse of a member of the organization about the delay in substituting the managers after the change of government).

Another action was the SATISFAZ Program established on 04/05/2001, with its main goal being to "transform SEFAZ into an excellent place to work" (SEFAZ NEWS, 2001c, p. 1). It is 
interesting to observe that the concept of the SATISFAZ Program had been the topic of earlier publications prior to the official launching of the program at least twice; in the issue of January/February 2001 in an article entitled "What it means to be the best organization to work for" and in the March/April 2001 issue in an article entitled "An excellent place to work". Officially the program was only launched in May 2001 in a special article in the May/June 2001 issue of SEFAZ NEWS

The actions related to SATISFAZ were about the improvement of internal work conditions. It sought among other things the "definition and implementation of actions that guarantee the improvement of work conditions and the satisfaction of the internal public" (SEFAZ NEWS, 2001d, p. 4). The program started an intensive process of visits to all the units with intent to "listen to complaints and suggestions in order to turn the bureau into a happy family". SATISFAZ began to occupy practically all the issues of the SEFAZ NEWS, a thing that the Quality Program had practically ceased to do.

In the first phase of the SATISFAZ Program, its figure ends up being associated with the topic of the big family of the treasury department. In a drive to make the bureau an excellent place to work at, the actions were always aimed at making the organizational environment pleasant for the practice of activities based on the ideas of "recognition, trust and cooperation" (SEFAZ NEWS, 2001d, p. 1). It is a vision closely based on the idea of cultural "glue" that, based on collective values, changes the organization into a true sharing of ideas, philosophies and specific beliefs and cultural values (Deal \& Kennedy, 2000; Schein, 2004).

The constant manipulations in the SATISFAZ are more subjective than those in previous programs. In this case, the strategy of lexical choices stands out. Words such as pleasure, family and satisfaction are parts of lexical choices to negotiate with the employees. Expressions like trust and cooperation appear often. Temptation is the strategy that stands out in this process, as rewards were promised for involvement in the program (Fiorin, 1997). At this point an observation is worth making regarding how individuals perceived the idea of a big family and how the latter was not successful in gathering the members of the organization together. This family is formed basically by three groups of workers: fiscal auditors, state tax agents and administrative technicians. The disagreements among these groups have always been marked by almost irreconcilable interests, mainly concerning their careers. The union has always defended some banners that were not the same as the ones of the fiscal auditors that were seen by the union as very close to the upper management because the managerial posts were always occupied by fiscal auditors.

These disagreements between these two groups grew, became exasperating with the proximity of the elections for the Bahia state government in 2006 and tense after the election since the winning government was from the opposition. The auditors and members of the board saw in this fact the loss of their privilege and acted to acquire some benefits at the end of their time in office regarding their career and retirement plans. On the other hand the union, an ally of the government that had won the election, saw in this occurrence the opportunity to conquer the benefits it had been trying the achieve for 10 years (Sindsefaz, 2007) and tried to distance themselves from the claims of the fiscal auditors.

Still, it can be seen that this disagreement reached a peak in April 2009 when the new state government made changes in the powers of two jobs (fiscal auditors and state tax agents) increasing the powers of the latter and consequently reducing those of the former. This created a large gap within the organization and the inner state of dissension spread to the field of personal relationships with individuals having heated discussions and creating an inner climate of a complete lack of brotherhood. The argument ended up in court. Each of the groups proclaimed to be the winner of this lawsuit and announced the strong points of their arguments. This caused more internal tension. Occurrences like this one show that there is no big family in this organization and that the discourse as an organizational myth and its ways of manipulation were unable to achieve the desired goals. In public organizations and perhaps precisely in public administration it is very difficult to create specific myths or cultural values because of the lack of bonds or ways to control individuals. These elements are not exactly verified in the public administration. Moreover the cultural unity supposed by the 
higher administration based on the idea of culture as a glue has more difficulty to stick the individuals to one another and to the organization. This leads to the consideration that the approach by Meyerson and Martin (1987) is more adequate when it comes to understanding how the individuals share specific values.

Moving forward in time, the SATIFAZ Program proposed new tools to motivate the employees to participate more actively in the organizational life. A contest of ideas was included in the program. Its goal is to award those ideas that help the organization increase its tax collection or reduce the cost of public administration. The topic of efficiency, of results and of creativity is heavily emphasized. It was already an object in the GDFISCO that among the different measured skills, creativity is listed. The contest of ideas was included in the program in June 2004.

Another element implemented in this process of the SEFAZ-BA's modernization that formally incorporates some elements of cultural value is strategic planning. As Schein (2004) states, among the cultural artifacts are the strategic plans of the organization, and in this case, formally by the bureau, the process of planning incorporated the values for the citizen, as the remaining aspects had already been explored previously.

The first strategic planning occurred in 2000. The following overall strategies for the organization were defined: (a) maintain fiscal balance; (b) obtain increased revenues; and (c) improve the quality of the services offered to the users of the SEFAZ-BA (SEFAZ NEWS, 2000b).

As of the year 2000 the organization had already introduced in the strategic planning figure the topic of innovation, transparency, ethics and social responsibility as described below: "Achieve excellence in fiscal administration being recognized as an innovative and efficient organization that values its professional staff and that is oriented towards transparency, ethics and social responsibility" (SEFAZ NEWS, 2000a).

The planning had two more editions, this first period being from 2001 to 2003. For the period of 2004 to 2006 new overall goals were set as well as for 2008 to 2011. These listed in Table 1.

Table 1

Strategic Goals of the Organization

\begin{tabular}{ll}
\hline \multicolumn{1}{c}{$\mathbf{2 0 0 4 - 2 0 0 6}$} & \multicolumn{1}{c}{$\mathbf{2 0 0 8 - 2 0 1 1}$} \\
\hline Real Growth of Tax Collection & Real Growth of Revenue \\
Maintenance of Fiscal Balance & Scope of Fiscal Balance \\
Quality of Public Expenditure & Pursuit of Excellence in People Management \\
& Improvement in Quality of Service \\
\hline
\end{tabular}

Note. Source: Secretaria da Fazenda. (2003c, fevereiro). Anunciadas metas globais para a Sefaz. SEFAZ NEWS, ano VIII, p. 4; Secretaria da Fazenda. (2008). Planejamento estratégico 2008 - 2011 (p. 3). (Relatório de planejamento), Salvador, BA, Autor.

In this planning process some aspects continue to be valued as is the case of tax collection growth and fiscal balance, a normal fact for an organization whose business is tax collection. However, for 2004-2006, the focus on the client disappears, being substituted by the pursuit of quality in public expenditure. However, in 2008 - 2011, the quality of service reappears and the pursuit of excellence in people management is included as a strategic goal.

The Career Plan of the FISCO Group was implemented in March 2003. It represented not only an expectation of the employees, but also of the senior management itself because the lack of a career plan had always been an issue of internal discord between employees, unions and senior management. 
It can be noted, however, that several trials to implement a career plan had been made, but without success because of the extent of the disagreements regarding the aspects of the plan.

The establishment of a career plan had been discussed since the beginning of the modernization process. It was included in the project submitted to the PNAFE as part of the commitments assumed by the organization as a goal to be implemented, and failure to do so could hinder new financing for new modernization processes.

The pressure to develop a new career plan has always been intense and from 1996 on it has taken an external dimension because of the relations established by the organization with funding agencies. In this way it is necessary to "design and implant a plan for job positions, functions and career defining profile, skills and professional training required according to the particularities of each area" (Sefaz, 1997, p. 68).

The Career Plan reinforces some issues considered important for the organization that had already been dealt with in other previous actions, i.e. meritocracy and strengthening of selfdevelopment. An attempt to change focus in the evaluation process for career improvement is also highlighted and this has led to a great deal of controversy within the organization. The fact is that the first framing within the classes was done taking into account time served in the SEFAZ-BA and other pre requirements such as academic education. This generated a great deal of dissatisfaction because people who had been in the organization for decades, but had never gone to college, were framed in lower categories in the new career plan. This issue is mentioned as follows:

The most important thing of all this was in fact the inclusion of training and performance as the decisive factors for career development/growth rather than the factor 'time served', which although impossible to eliminate had its importance reduced to only one third in the total value of the promotion (Sefaz, 2003, p. 13).

Furthermore, for future promotions, total time served in the organization was made relative as it is no longer an indicator for promotion, something always appreciated in public service. Hence, the organization places more emphasis on evaluating performance and pursuit of self development in terms of formal education and training rather than time served in the public sector.

The career plan manipulates individuals through temptation (Fiorin, 1997), showing the possibilities of ascension in their career and it also emphasizes lexical choices such as development, promotion, salary increase (M. M. P. Souza et al., 2009). In all these discourses the comprehension of Marini (1996) can be identified when considering that an organizational change in the public sector would necessarily involve a change of staff, i.e., either there is a change in the staff that make up the public sector or the planned reforms will be unsuccessful. Moreover, associated with this assumption is the functionalist view of organizational culture.

For this group, organizational culture can be a manageable element that can be manipulated and controlled, in addition to being changed by managerial actions (Deal \& Kennedy, 2000; Ouchi, 1982; Schein, 2004). It is the concept that culture is a competitive advantage and that its change will bring greater advantages to an organization in comparison to other organizations (Alvesson \& Berg, 1992; Alvesson, 2007).

\section{Conclusions}

This work investigated how the upper management used different discourse resources to develop new cultural values. Considering that discourse and culture are interwoven (Alvesson, 2004), the discourse strategies are useful for the creation and spreading of a new organizational culture. It can be seen that the organization spread these new values through various material means used as figures that reproduced the desired themes or cultural values. Moreover, it could also be noted that the 
organization made the procedures operational using various tools of convincing such as seduction, temptation, intimidation and provocation.

Discourse works as a source of power. The group that has the opportunity to control the production of discourses certainly has the chance to control the production of senses in organizations (Hardy \& Phillips, 2004). It was no different in this organization.

The controller of the official means of production of the discourses seeks to build the senses that would be necessary to see shared in the organization and thinks to develop, based on its discourse, these new values and meanings. One of the examples is the myth of the big family and of teamwork, and it is already possible to give some thought to how these discourses have or have not found space within the organization.

Sainsaulieu (1997) believes that myths serve as an instrument of domination of the work collectivity and part of the actors of the organization perceive the action of the upper management in such a way. The idea of the big family of the personal and professional development among others would only serve to minimize conflicts. This perception greatly reduced the pace of the introduction of the planned reforms and modified the course of others. It was noted that the discourse of the upper management seems incapable of influencing the different groups within the organization decisively, and this would hinder the organization when attempting to develop the new desired values. The instruments that were introduced suffered resistance during their phase of introduction due to the various perceptions of the inner groups. The organizational discourse was seen as a manipulator in which there are other hidden things behind it or who knows they want with this to lay us off in the future. These are some of the interpretations given to the artifacts or figures included in the organizational context. As stated by Sahlins (1997) the events are interpreted based on the set of meanings that the individuals already possess and then reinterpret every event included in its context.

And it is from this reinterpretation that individuals take their stance regarding these new elements. To each of these figures, the organizational actors give a meaning that is not necessarily the same as that of the upper management. In the public sector, the challenge of discovering that values or meanings penetrate the imagination of the members of these organizations remains. If these are not the values that guide the behavior of the individuals within the organization, which would the guides of behavior actually be? This question still remains unanswered. There is talk about a culture inherited from the Portuguese that is believed to have great influence on the present behavior because the culture is the result of a historical process (Sahlins, 1997). Notwithstanding, culture is also the product of social changes that societies and organizations undergo (Sahlins, 1997) or as Laraia (2001) believes, cultures transform themselves through external and internal processes based on their own logic. This comprehension makes it difficult to continue stating that public organizations have unchangeable organizational cultures such as the interests of groups and external influences are determinants for the advance of the process of cultural change in public organizations.

This work sets the challenge to investigate the cultural values that are found in public organizations. Unlike the discourses that "everything continues as it was in the early days of Brazil" the discourse of the upper management seems already to be penetrated by new objectives, even though it has not been able to influence important changes in the organization and in its members. Contrary to the discourses that the public organizations continue in the same way and without any perspectives of change, the process that was begun by this organization indicates a possibility of guiding public organizations towards values that enable them to achieve their goals in society.

\section{Received 04 March 2010; received in revised form 23 August 2010.}




\section{References}

Aktouf, O. (1994). O simbolismo e a cultura de empresa: dos abusos conceituais às lições empíricas. In J. F. Chanlat (Coord.), O indivíduo na organização: dimensões esquecidas (pp. 39-79). São Paulo: Atlas.

Alvesson, M. (2004). Organizational culture and discourse. In D. Grant, C. Hardy, C. Oswick, \& L. Putnam (Eds.), The sage handbook of organizational discourse (pp. 317-335). London: Sage Publications.

Alvesson, M. (2007). Understanding organizational culture. London: SAGE Publications.

Alvesson, M., \& Berg, P. O. (1992). Corporative culture and organizational symbolism: an overview. New York: Walter de Gruyter.

Bakhtin, M. (1993). Questões de literatura e de estética: a teoria do romance. São Paulo: Editora UNESP.

Bresser-Pereira, L. C. (1998). Reforma do Estado para a cidadania: a reforma gerencial brasileira na perspectiva internacional. São Paulo: Editora 34.

Deal, T. E., \& Kennedy, A. (2000). Corporate cultures. The rites and rituals of corporate life. Cambridge: Basic Books.

Dupuis, J. P. (1996). Antropologia, cultura e organizações: proposta de um modelo construtivista. In J. F. Chanlat (Org.), O indivíduo na organização: dimensões esquecidas (Vol. 3, pp. 231-251). São Paulo: Atlas.

Fadul, E., \& Souza, A. R. (2005, setembro). Políticas de reformas da administração pública brasileira: uma compreensão a partir de seus mapas conceituais Anais do Encontro Nacional da Associação Nacional de Pós-Graduação e Pesquisa em Administração, Brasília, DF, Brazil, 29.

Fiorin, J. L. (1997). Elementos de análise do discurso (6th ed.). São Paulo: Contexto.

Fiorin, J. L. (2007). Linguagem e ideologia (8th. ed.). São Paulo: Ática.

Gagliardi, P. (2001). Explorando o lado estético da vida organizacional. In S. R. Clegg, C. Hardy, \& W. R. Nord (Orgs.), Handbook de estudos organizacionais (Vol. 2, pp. 127-149). São Paulo: Atlas.

Geertz, C. (1989). A interpretação das culturas. Rio de Janeiro: LTC.

Grant, D., Hardy, C., Oswick, C., \& Putnam, L. L. (2004). Introduction: organizational discourse: exploring the field. In D. Grant, C. Hardy, C. Oswick \& L. L. Putnam (Eds.), The sage handbook of organizational discourse (pp. 1-36). London: Sage Publications.

Hardy, C., Laurence, T. B., \& Phillips, N. (1998). Talk and action: conversations and narrative in interorganizational collaboration. In D. Grant, T. Keenoy, \& C. Oswick (Eds.), Discourse and organization (pp. 65-83). London: SAGE Publication.

Hardy, C., \& Phillips, N. (2004). Discourse and power. In D. Grant, C. Hardy, C. Oswick, \& L. Putnam (Eds.), The sage handbook of organizational discourse (pp. 299-316). London: Sage Publications.

Hofstede, G. (2003). Culturas e organizações. Compreender a nossa programação mental (2nd ed.). Lisboa: Edições Silabo. 
Kotter, J. P., \& Heskett, J. L. (1992). Corporate culture and performance. New York: The Free Press.

Laraia, R. B. (2001). Cultura: um conceito antropológico (14th ed.). Rio de Janeiro: Jorge Zahar.

Machado-da-Silva, C. L., \& Nogueira, E. E. S. (2000). Instituições, cultura e identidade organizacional. Curitiba: Cromo Editora.

Marini, C. M. F. (1996). Crise e reforma do Estado: uma questão de cidadania e valorização do Servidor. Revista do Servidor Público, 47(3), 5-33.

Marshak, R. J. (1998). A discourse on discourse: redeeming the meaning of talk. In D. Grant, T. Keenoy \& C. Oswick (Eds.), Discourse and organization (pp. 15-30). London: SAGE Publication.

Meyerson, D., \& Martin, J. (1987). Cultural change: an integration of three different views. Journal of Management Studies, 24(6), 623-647. doi: 10.1111/j.1467-6486.1987.tb00466.x

Ouchi, W. G. (1982). Teoria Z: como as empresas podem enfrentar o desafio japonês. São Paulo: Ed. Fundo Educativo Brasileiro.

Pettigrew, A. (1996). A cultura das organizações é administrável? In M. T. L. Fleury \& R. M. Fischer (Coords.), Cultura e poder nas organizações (2nd ed., pp. 145-153). São Paulo: Atlas.

Plano Diretor da Reforma do Aparelho do Estado. (1995). Ministério da Administração Federal e Reforma do Estado e Aprovado pela Câmara da Reforma do Estado e pela Presidência da República. Brasília, DF: MARE.

Programa Nacional de Apoio à Administração Fiscal para os Estados Brasileiros. (1996). Ministério da Fazenda. Retrieved July 23, 2009, from http://www.fazenda.gov.br/ucp/pnafe/

Sackmann, S. A. (1992). Culture and subcultures: an analysis of organizational knowledge. Administrative Science Quarterly, 37(1), 140-191.

Sahlins, M. (1997). Ilhas de história. Rio de Janeiro: Jorge Zahar Editor.

Sainsaulieu, R. (1997). L'identité au travail. Paris: Presses de la Fondation Nationale des sciences politiques.

Schein, E. (2004). Organizational culture and leadership (3rd ed.). San Francisco: Jossey-Bass.

Schwartz, S. H. (1994). Are there universal aspects in the structure and contents of human values? Journal of Social Issues, 50(4), 19-45. doi: 10.1111/j.1540-4560.1994.tb01196.x

Secretaria da Administração. (2002). O processo de modernização do Estado da Bahia: os avanços de uma década - 1991 - 2001. Empresa Gráfica da Bahia.

Secretaria da Fazenda. (1997). Programa de modernização da Secretaria da Fazenda: projeto de modernização e racionalização da administração tributária (Relatório de Diagnóstico), Salvador, BA, Autor.

Secretaria da Fazenda. (1998). Modelo de revisão organizacional (Relatório de diagnóstico), Salvador, BA, Autor.

Secretaria da Fazenda. (2003). Quando o santo de casa faz milagre: um caso de mudança cultural bem sucedido no serviço público (Relatório de avaliação), Salvador, BA, Autor.

Secretaria da Fazenda. (2008). Planejamento estratégico 2008 - 2011 (Relatório de planejamento), Salvador, BA, Autor. 
Secretaria da Fazenda. (2000a, dezembro). Ações de RH e infra-estrutura melhoram condições de trabalho na Sefaz. SEFAZ NEWS, ano VI, p. 3.

Secretaria da Fazenda. (2000b, novembro). Sefaz divulga plano de ação e desenvolvimento. SEFAZ NEWS, ano VI, p. 3.

Secretaria da Fazenda. (2001a, agosto/setembro). Inspetorias das DATs Norte e Sul realizam ações de qualidade. SEFAZ NEWS, ano VII, p. 5.

Secretaria da Fazenda. (2001d, junho/julho). Programa Satisfaz finaliza visitas à DAT-Metro e promove primeiras ações. SEFAZ NEWS, ano VII, pp. 1-4.

Secretaria da Fazenda. (2001b, dezembro). Projetos realizados no ano são base para uma nova fase de modernização. SEFAZ NEWS, ano VII, p. 5.

Secretaria da Fazenda. (2001c, março/abril). Um excelente lugar para se trabalhar. SEFAZ NEWS, ano VII, p. 1.

Secretaria da Fazenda. (2002a, agosto/setembro). Inspetorias consolidam novo padrão Sefaz. SEFAZ NEWS, ano VII, p. 5.

Secretaria da Fazenda. (2002b, novembro/dezembro). Sefaz lança gestão de desempenho. SEFAZ NEWS, ano VII, pp. 4-5.

Secretaria da Fazenda. (2003c, fevereiro). Anunciadas metas globais para a Sefaz. SEFAZ NEWS, ano VIII, p. 4.

Secretaria da Fazenda. (2003a, abril/maio). Gestão por desempenho atinge toda a sefaz. SEFAZ NEWS, ano VIII, p. 3.

Secretaria da Fazenda. (2003b, julho). Meritocracia: a filosofia é boa; a prática, melhor ainda. SEFAZ NEWS, ano VIII, pp. 2-4.

Sindicato dos Servidores da Fazenda do Estado da Bahia. (2010, janeiro 27). Sindsefaz executa a ação do PDF. Boletim eletrônico do SindSefaz (511). Retrieved July 23, 2009, from http://www.sindsefaz.org.br/BOLETINS/boletim_511.htm

Sillince, J. A. A. (2007). Organizational context and the discursive contruction of organizing. Managemente Communication Quarterly, 20(4), 363-394. doi: 10.1177/0893318906298477

Souza, C. R. S. (2002, Outubro). Secretaria da fazenda do estado da Bahia: um case de transformação organizacional através da tecnologia da informação. Anais do Congresso Internacional Del CLAD sobre la Reforma Del Estado y de la Administración Pública, Lisboa, Portugal, 7.

Souza, M. M. P., Carrieri, A. P., \& Faria, A. A. M. (2009). A projeção da identidade organizacional: um estudo da identidade de uma ferrovia privatizada. In A. P. Carrieri, L. A. S. Saraiva, T. D. Pimentel, \& P. A. G. Souza-Ricardo (Orgs.), Análise do discurso em estudos organizacionais (pp. 249-275). Curitiba: Juruá.

Woodilla, J. (1998). Workplace conversations: the text of organizing. In D. Grant, T. Keenoy, \& C. Oswick (Eds.), Discourse and organization (pp. 31-50). London: SAGE Publications. 